
\title{
SMITH-LEMLI-OPITZ SYNDROME (SLOS): CASE REPORT AND
SYMPTOMATIC TREATMENT
}

\begin{abstract}
Smith-Lemli-Opitz syndrome is a rare syndrome with multiple congenital anomalies after birth and characteristic with mental retardation. Hereditary cholesterol diseases are an autosomal recessive form of metabolic disturbances. There are two types: Type I with mild clinical signs (classical form) and Type II with severe clinical signs. The Type I form with a higher chance of survival is more common. There are typical craniofacial findings such as microcephaly, low-set ears, micrognathia, flattened nasal root and bitemporal narrowing. Cleft palate and/or deep palate enlarged alveolar bones, small-sized tongue and swallowing strength are noticeable mouth-related findings. Patients recover at a certain rate with early medical treatment. Early dental treatments are based on eliminating symptomatic problems. A 3-week-old male patient presented with a deep palate, swallowing difficulty, a problem of nourishment, and SLOS Type I was presented.
\end{abstract}

Keywords: RSH-SLO syndrome, maxillary diseases, alveolar bone, palatal expansion technique.
*Taner Ozturk ${ }^{1}$

(iD) Nisa Gul Amuk ${ }^{1}$

ORCID IDs of the authors: T.Ö. 0000-0003-1670-286X N.G.A. 0000-0002-3752-7100

${ }^{1}$ Department of Orthodontics, Faculty of Dentistry, Erciyes University, Kayseri

How to Cite: Ozturk T, Amuk NG. Smith-Lemli-Opitz Syndrome (SLOS): Case Report and Symptomatic Treatment. Cumhuriyet Dent J 2019;22:2:245-250.

Department of Orthodontics, Faculty of Dentistry, Erciyes University, 38039 Melikgazi, Kayseri, Turkey

Phone: +90 5331680466 Fax: +90 3524380657 E-mail: tanertr35@gmail.com 


\section{INTRODUCTION}

Smith-Lemli-Opitz Syndrome (SLOS) is an autosomal recessive disorder characterized by multiple congenital anomalies and seen with the prevalence of $1 / 20,000-60,000$ in Hispanics. ${ }^{1-5}$ The syndrome, where insufficient growth, developmental retardation and congenital defects are seen, was first described by Smith et al. ${ }^{1}$ This syndrome is caused by a mutation on the enzyme level at the last stage of cholesterol biosynthesis (7-dehydrocholesterol; 7-DHC)(5-7). ${ }^{1}$ Thereby, the cholesterol levels are low in SLOS cases. ${ }^{6-10}$ According to clinical observation and prognosis, there are two types as the classical form (Type I) and the severe form (Type II). In Type I SLOS, clinical manifestations are milder, and life span is more prolonged. ${ }^{1,11}$

The craniofacial findings are microcephaly, ears positioned below the normal level and facing backward, dysmorphic facial findings, bitemporal narrowing, ptosis, flattened nose root, outward nostrils, micrognathia, (isolated) cleft palate, deep palate, bifid uvula, enlarged alveolar bone sclerosis, enamel hypoplasia, oligodontia -

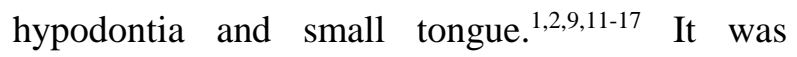
reported that $40-50 \%$ of patients with SLOS have an isolated cleft palate deformity, and newborns with SLOS suffer from swallowing difficulty due to cleft or deep palate. ${ }^{12,14,18}$ For this reason, feeding infants with SLOS may be inadequate for a normal growth pattern. Other clinical findings include prenatal and postnatal developmental retardation, moderate-severe mental retardation, polydactyly, congenital heart diseases, pulmonary vein disorders, urogenital disorders accompanied by inadequate external genital organs, hypotonicity and syndactyly between the second and third toes. ${ }^{1,12-19}$ Despite the limited number of case reports, a symptomatic treatment approach to facilitate nutrition has not been previously presented. The aim of this case report is to present a newborn with SLOS, review the information in the literature and discuss the current treatment options. This method will be the first method applied to the upper jaw for the symptomatic treatment of a patient.

\section{CASE REPORT}

Informed consent: Written informed consent was obtained from the parents of the patient who participated in this study.

A 3-week-old newborn male patient was admitted to the Department of Orthodontics at the Faculty of Dentistry at Erciyes University with complaints of deep palate dome, swallowing difficulty, nourishment and constant vomiting problems (Figure 1).

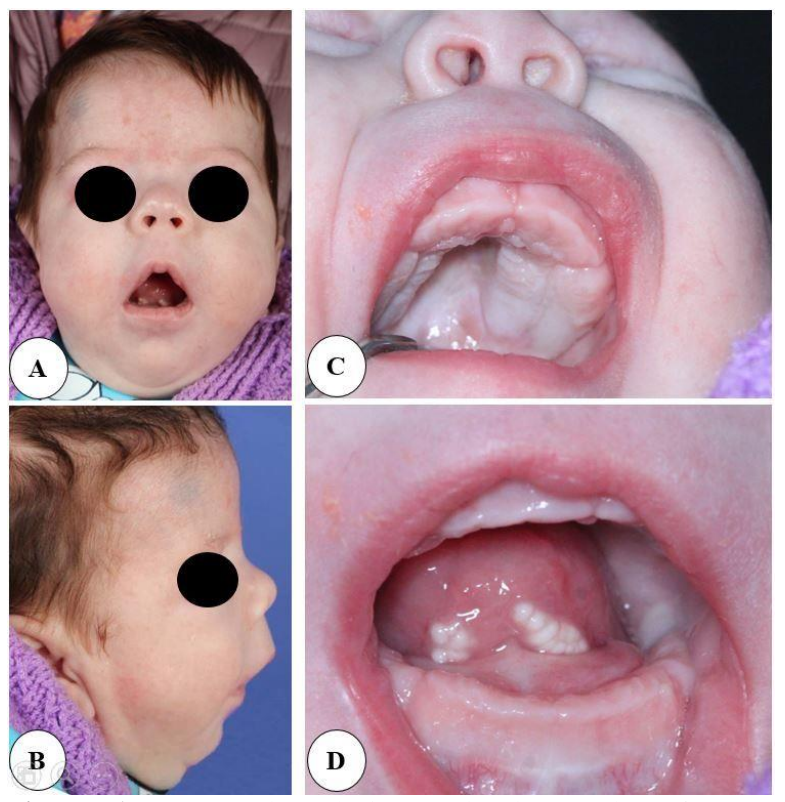

Figure 1. Extra-oral and intra-oral photographs of SLOS patient. A)Frontal view. B) Profile view. C)Appearance of maxilla and deepened palate dome. D) Appearance of mandible and sublingual nodule-like formations.

The diagnosis of SLOS Type I in the patient was made according to the results of his blood cholesterol levels and the clinical examination by the Endocrine Science Department of Child Metabolism at Erciyes University, Faculty of Medicine. The patient was recommended to use medication for correction of cholesterol levels, had an operation on the heart and soft tissue syndactyly between the right second and third toes. Because the circumference of the head was measured as $36 \mathrm{~cm}$, it was found below the $3 \mathrm{rd}$ percentile according to the Turkish population, and therefore, the patient was diagnosed with microcephaly. Other physical examination findings (height: $48 \mathrm{~cm}$, weight: $3.3 \mathrm{~kg}$ ) also indicated that the patient was below the 3rd percentile, because the percentile values such as a head circumference of about $41 \mathrm{~cm}, 58 \mathrm{~cm}$ of height and $4.2 \mathrm{~kg}$ of weight of normal male patients without the syndrome were accepted to be 
normal values. ${ }^{20}$ Along with this, other clinical findings of the patient with SLOS were reported as ambiguous genitalia, syndactyly, bitemporal narrowing, hypotonicity in the neck muscles, flattened nasal roots, low-set ears, deep and narrow palate, broad upper and lower alveolar edges (Figure 2), yellow nodule formation under the tongue, difficulty in swallowing, nutritional problems and vomiting by the Endocrine Science Department of Child Metabolism, the Faculty of Medicine and the Department of Orthodontics, the Faculty of Dentistry at Erciyes University.

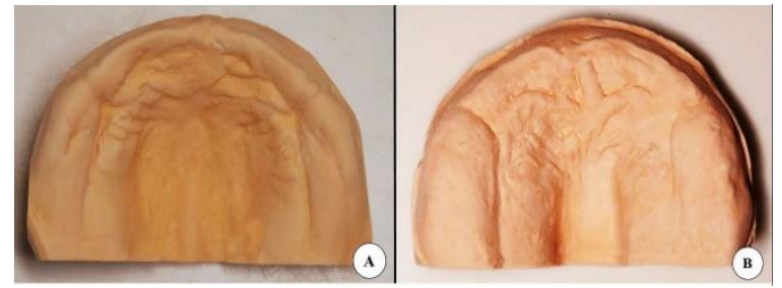

Figure 2. A) Maxillary dental model of normal new-born. B) Maxillary dental model of patient with SLOS.

\section{Symptomatic treatment approach}

A symptomatic treatment approach was planned to enlarge the oral chamber, expand the tongue chamber, reduce the deepness of the palate by decreasing the depth of the palate and allowing negative pressure formation in the mouth during swallowing. A maxillary dental model (Figure 2) was prepared by using hard dental gypsum from the maxillary dental impression, which was obtained with a silicone impression material. A removable appliance was applied to the maxilla in order to help the patient nourish and enlarge the narrow maxillary dental arches (Figure 3).

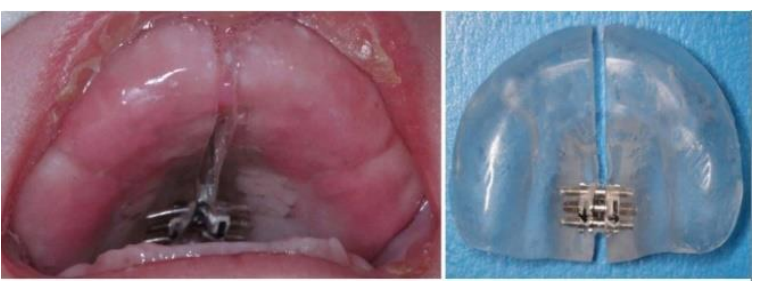

Figure 3. Maxillary expansion of SLOS patient, using a modified acrylic feeding plate with a widening screw.

The expansion screw was activated for a $1 / 4$ turn per week ( 1 turn $=1 \mathrm{~mm} ; 1 / 4$ turn $=0.25 \mathrm{~mm})$. Screw activation was continued for the first 4 months. The analysis of the maxillary dental models was performed on the images obtained by a 3D model scanner (3Shape, Copenhagen, Denmark) and the OrthoAnalyzer (3Shape, Copenhagen, Denmark) software (Figure 4).

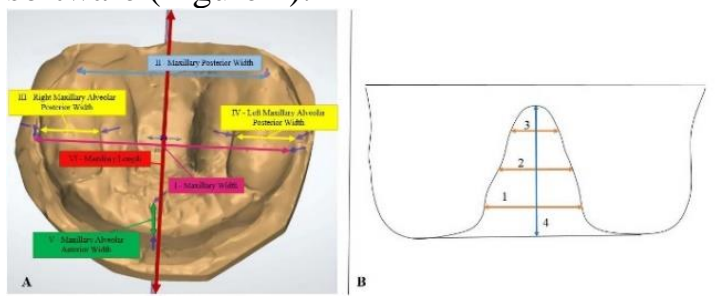

Figure 4. A)I. Maxillary Width, II. Maxillary Posterior Width, III. Right Maxillary Alveolar Posterior Width, IV. Left Maxillary Alveolar Posterior Width, V. Maxillary Alveolar Anterior Width, VI. Maxillary Length. B)1. Palatal dome width (Maximum width between alveolar crest peaks), 2. Palatal dome low level 1 width (at the midpoint of the maxillary depth), 3. Palatal dome low level 2 width (close to $1 / 4$ of the maxillary depth), 4. Maxillary Depth (distance between the highest point of the alveolar crest and deepest point of the palatal dome).

An increase of $4.49 \mathrm{~mm}$ in maxillary width was found in the treated SLOS case, while the developmental increase of the maxillary width of a control subject who was born at the same time as the syndromic new-born had normal development within its percentile. As seen in the change of maxillary depth, a decrease of -0.44 $\mathrm{mm}$ in the SLOS case and an increase of $2.13 \mathrm{~mm}$ in the normal new-born were detected (Table 1).

Table 1. Evaluation and comparison of maxillary development of SLOS case and control subject

\begin{tabular}{|c|c|c|c|c|c|c|}
\hline & \multicolumn{3}{|c|}{ Patient with SLOS } & \multicolumn{3}{|c|}{ Control subject } \\
\hline & T0 (3rd week) & T1 (7th month) & Differences & T0 (3rd week) & T1 (7th month) & Differences \\
\hline Maxillary length & $32.50 \mathrm{~mm}$ & $33.15 \mathrm{~mm}$ & $0.65 \mathrm{~mm}$ & $37.62 \mathrm{~mm}$ & $40.15 \mathrm{~mm}$ & $2.53 \mathrm{~mm}$ \\
\hline Maxillary depth & $13.57 \mathrm{~mm}$ & $13.13 \mathrm{~mm}$ & $-0.44 \mathrm{~mm}$ & $9.12 \mathrm{~mm}$ & $11.25 \mathrm{~mm}$ & $2.13 \mathrm{~mm}$ \\
\hline Maxillary width & $36.40 \mathrm{~mm}$ & $40.89 \mathrm{~mm}$ & $4.49 \mathrm{~mm}$ & $39.50 \mathrm{~mm}$ & $41.26 \mathrm{~mm}$ & $1.76 \mathrm{~mm}$ \\
\hline Anterior alveolar width & $5.15 \mathrm{~mm}$ & $6.40 \mathrm{~mm}$ & $1.25 \mathrm{~mm}$ & $6.19 \mathrm{~mm}$ & $7.01 \mathrm{~mm}$ & $0.82 \mathrm{~mm}$ \\
\hline $\begin{array}{l}\text { Posterior alveolar width } \\
\text { (right) }\end{array}$ & $8.30 \mathrm{~mm}$ & $10.21 \mathrm{~mm}$ & $1.91 \mathrm{~mm}$ & $7.12 \mathrm{~mm}$ & $8.15 \mathrm{~mm}$ & $1.03 \mathrm{~mm}$ \\
\hline $\begin{array}{c}\text { Posterior alveolar width } \\
\text { (left) }\end{array}$ & $8.50 \mathrm{~mm}$ & $11.49 \mathrm{~mm}$ & $2.99 \mathrm{~mm}$ & $7.8 \mathrm{~mm}$ & $8.6 \mathrm{~mm}$ & $0.8 \mathrm{~mm}$ \\
\hline Palatal dome width & $17.15 \mathrm{~mm}$ & $20.67 \mathrm{~mm}$ & $3.52 \mathrm{~mm}$ & $17.95 \mathrm{~mm}$ & $19.26 \mathrm{~mm}$ & $1.31 \mathrm{~mm}$ \\
\hline $\begin{array}{c}\text { Palatal dome low level } 1 \\
\text { width }\end{array}$ & $8.30 \mathrm{~mm}$ & $9.87 \mathrm{~mm}$ & $1.57 \mathrm{~mm}$ & $9.92 \mathrm{~mm}$ & $10.56 \mathrm{~mm}$ & $0.64 \mathrm{~mm}$ \\
\hline $\begin{array}{c}\text { Palatal dome low level } 2 \\
\text { width }\end{array}$ & $7.60 \mathrm{~mm}$ & $8.42 \mathrm{~mm}$ & $0.82 \mathrm{~mm}$ & $9.11 \mathrm{~mm}$ & $10.26 \mathrm{~mm}$ & $1.15 \mathrm{~mm}$ \\
\hline Weigth & $3.4 \mathrm{~kg}$ & $4.7 \mathrm{~kg}$ & $1.3 \mathrm{~kg}$ & $4.2 \mathrm{~kg}$ & $7.4 \mathrm{~kg}$ & $3.2 \mathrm{~kg}$ \\
\hline $\begin{array}{c}\text { The head circumference } \\
\text { measurement }\end{array}$ & $36 \mathrm{~cm}$ & $38 \mathrm{~cm}$ & $2 \mathrm{~cm}$ & $41 \mathrm{~cm}$ & $48 \mathrm{~cm}$ & $7 \mathrm{~cm}$ \\
\hline
\end{tabular}


Although the amount of vomiting decreased during the treatment, the swallowing difficulty continued partially in the patient, and there was insufficient weight gain (from $3.4 \mathrm{~kg}$ to $4.7 \mathrm{~kg}$ in 6 months) as expected, because his syndrome was very severe, and the parents of the SLOS patient did not show co-operation for both the medical and orthodontic treatments of the patient. During the monitoring period, the sublingual nodule-like structures previously reported by Merrer $^{21}$ disappeared, which indicated regulation of the cholesterol metabolism. However, despite the fact that expansion of the maxilla was achieved, he was still fed by a nasogastric probe.

\section{DISCUSSION}

SLOS is a congenital cholesterol metabolism disease which manifests various intra-oral findings and needs to be intervened with in the early period. $1,11,12$ It is necessary to help improvement of nutrition in cases with cleft palate and/or deep palate. However, these patients usually have difficulty in swallowing. Providing early cholesterol regulation may substantially reduce the symptoms of this syndrome. ${ }^{21,22}$ Medical treatment may increase the rate of retarded growth, accelerate the developmental process and decrease the rate of dermatological, gastrointestinal and infectious diseases. ${ }^{23} \mathrm{~A}$ normal male new-born with the same age as and similar weight to the patient with SLOS was selected as the control subject and was followed for 6 months. The increase in the alveolar crest width of the SLOS patient was greater than that in the normal patient. Weight gain in the normally developed new-born was $20 \%$ (from 4 to $7.5 \mathrm{~kg}$ ), while the weight gain in the SLOS patient was about $10 \%$ (from 3.4 to $4.7 \mathrm{~kg}$ ) (Table 1). Moreover, the weight gain and growth values were similar to those reported by Lee et al. ${ }^{24}$ Individuals with this disease are usually found to be below normal developmental stages., 1, 20, 24 Therefore, the development of our patient was below the 3 rd percentile. The increase rate of the maxillary width was greater than the normal patient because an expansion appliance was used.

The variation of medical and dental history should be considered to describe the factors that may be effective in terms of dental treatment, since various complications may occur in patients affected by SLOS. A symptomatic approach of primary orthodontic treatment in the early period was presented in this report. A nutritional plaque beside an expansion screw was applied to the SLOS patient to improve the nutritional status of the patient. In the case of a deep palate, placement of a widening screw in the nutritional plaque may provide additional benefits to reduce the existing depth. The improvement under expectation with the nutritional expansion plaque was thought to be due to the incompliance of the parents with the use of the appliance as instructed and retention problems in the mouth. Further practices may focus on solving the retention problem of appliances in toothless new-born mouth. In our patient, there were difficulties in swallowing and use of the appliance since the restraint and undercuts of the maxillary alveolar bone were insufficient. Because of these reasons, the patient could not get enough benefit from nutrition.

\section{CONCLUSIONS}

It is important to know the characteristic findings of SLOS and other rare syndromes, on which the level of knowledge is low, to provide treatment options for such patients. Determination and interpretation of intra-oral and extra-oral clinical findings would be sufficient for the necessary consultations with the department of child metabolism and the department of medical genetics for the accurate diagnosis which is extremely important for the detailed orofacial and dental treatment of the patient.

\section{ACKNOWLEDGEMENTS}

The authors declared that this study received no financial support.

\section{CONFLICT OF INTEREST}

The authors have no conflict of interest to declare.

Smith-Lemli-Opitz Sendromu (Slos): Olgu Sunumu
ve Semptomatik Tedavisi
$\ddot{O} Z$

Smith-Lemli-Opitz sendromu, doğum sonrası multipl konjenital anomaliler ve mental retardasyon ile birlikte karakteristik bulguları olan nadir görülen bir sendromdur. Kalttimsal kolesterol metabolizma bozukluklarinın otozomal resesif geçisli bir formudur. 
Hafif klinik özelliklerle seyreden (klasik form) Tip I ve şiddetli klinik özelliklerle seyreden (Tip II) olmak üzere iki tipi vardır. Yaşama şansı yüksek olan tip I formu daha slklkkta görülmektedir. Mikrosefali, düşük kulaklar, mikrognati, bası burun kökü ve bitemporal darlik gibi tipik kraniofasial bulguları mevcuttur. Yarlk damak velveya derin damak, genişlemiş alveolar kemikler, küçük boyutlu dil ve yutkunma güçlügü dikkat çeken ă̆ız bulgularıdır. Hastalar erken dönemde aldı̆g medikal tedavi ile belirli oranlarda iyileşme göstermektedirler. Erken dönemde uygulanan dental tedaviler semptomatik problemlerin giderilmesi üzerine olmaktadır. Derin damak, yutkunma güçlüğü, beslenememe problemi ile getirilen ve SLOS tip I tanisl konmuş 3 haftalı erkek hastanin sunumu yapıld. Anahtar Kelimeler; RSH-SLO sendromu, maksilla hastallklarl, alveol kemiği, damak genişletme tekniği.

\section{REFERENCES}

1. Smith DW, Lemli L, Opitz JM. A newly recognized syndrome of multiple congenital anomalies. J Pediatr. 1964;64:210-217.

2. Muzzin KB, Harper LF. Smith-Lemli-Opitz syndrome: a review, case report and dental implications. Spec Care Dentist. 2003;23:22-27.

3. Opitz JM, Penchaszadeh VB, Holt MC, Spano LM, Smith VL. Smith-Lemli-Opitz (RSH) syndrome bibliography: 1964-1993. Am J Med Genet. 1994;50:339-343.

4. Ryan A, Bartlett K, Clayton P, Eaton S, Mills L, Donnai D, Winter RM, Burn J. Smith-Lemli-Opitz syndrome: a variable clinical and biochemical phenotype. J Med Genet. 1998; 35:558-565.

5. Yu H, Patel SB. Recent insights into the SmithLemli-Opitz syndrome. Clin Genet. 2005;68:383-391.

6. Nowaczyk MJM, Irons MB. 2012. Smith-LemliOpitz syndrome: Phenotype, natural history, and epidemiology. Am J Med Genet Part C Semin Med Genet 160C: 250-262.

7. Battaile KP, Steiner RD. Smith-Lemli-Opitz syndrome: the first malformation syndrome associated with defective cholesterol synthesis. Mol Genet Metab. 2000;71:154-162.

8. Tint GS, Irons M, Elias ER, Batta AK, Frieden R, Chen TS, Salen G. Defective cholesterol biosynthesis associated with the Smith-Lemli-Opitz syndrome. N Engl J Med. 1994;330:107-113.

9. Bianconi SE, Cross JL, Wassif CA, Porter FD. Pathogenesis, epidemiology, diagnosis and clinical aspects of Smith-Lemli-Opitz syndrome. Expert Opin Orphan Drugs 2015;3:267-280.

10. Porter FD, Herman GE. Malformation syndromes caused by disorders of cholesterol synthesis. J Lipid Res 2011;52:6-34.

11. Curry CJ, Carey JC, Holland JS, Chopra D, Fineman R, Golabi M, Sherman S, Pagon RA, Allanson J, Shulman S, Barr M, McGravey V, Dabiri C, Schimke N, Ives E, Hall B. Smith-Lemli-Opitz syndrome-type II: Multiple congenital anomalies with male pseudohermaphroditism and frequent early lethality. Am J Med Genet. 1987;26:45-57.

12. Cunniff C, Kratz LE, Moser A, Natowicz MR, Kelley RI. Clinical and biochemical spectrum of patients with RSH/Smith-Lemli-Opitz syndrome and abnormal cholesterol metabolism. Am J Med Genet. 1997;68:263-269.

13. Kelley RI, Hennekam RC. The smith-lemli-opitz syndrome. J Med Genet. 2000;37:321-335.

14. Blair HR, Martin J. A syndrome characterized by mental retardation, short stature, craniofacial dysplasia, and genital anomalies occurring in siblings. J Pediatr. 1966;69:457-459.

15. Dallaire L. Syndrome of retardation with urogenital and skeletal anomalies (Smith-Lemli-Opitz syndrome): clinical features and mode of inheritance. J Med Genet. 1969;6:113.

16. Porter FD. Smith-Lemli-Opitz syndrome: pathogenesis, diagnosis and management. Eur $\mathbf{J}$ Hum Genet. 2008; 16:535.

17. Antoniades K, Peonidis A, Pehlivanidis C, Kavadia $S$, Panagiotidis P. Craniofacial manifestations of Smith-Lemli-Opitz syndrome: case report. Int J Oral Maxillofac Surg. 1994;23:363-365.

18. Merkens MJ, Sinden NL, Brown CD, Merkens LS, Roullet J-B, Nguyen T, Steiner RD. Feeding impairments associated with plasma sterols in SmithLemli-Opitz syndrome. J Pediatr. 2014;165:836-841.

19. Gorlin, R. J., \& Pindborg, J. J. Syndromes of the head and neck, New York. McGraw-Hill Book Company, Inc., chaps, 19, 1964:51-69.

20. Neyzi O, Günöz H, Furman A, Bundak R, Gökçay G, Darendeliler F. Türk çocuklarında vücut ağırlığı, boy uzunluğu, baş çevresi ve vücut kitle indeksi referans değerleri. Çocuk Sağlı̆̆ı ve Hastalıkları Dergisi. 2008;51:1-14.

21. Merrer M, Briard M, Girard S, Mulliez N, Moraine

$\mathrm{C}$, Imbert M. Lethal acrodysgenital dwarfism: a severe 
lethal condition resembling Smith-Lemli-Opitz syndrome. J Med Genet. 1988;25:88-95.

22. Jayamanne C, Sandamal S, Jayasundara K, Saranavabavananthan M, Mettananda S. Smith-LemliOpitz syndrome presenting as acute adrenal crisis in a child: a case report. J Med Case Rep. 2018;12:217.

23. Elias ER, Irons MB, Hurley AD, Tint GS, Salen G. Clinical effects of cholesterol supplementation in six patients with the Smith-Lemli-Opitz syndrome (SLOS). Am J Med Genet. 1997;68:305-310.

24. Lee RW, McGready J, Conley SK, Yanjanin NM, Nowaczyk MJ, Porter. Growth charts for individuals with Smith-Lemli-Opitz syndrome. Am J Med Genet A. 2012;158:2707-2713. 